〔22〕ポリ酢酸ビニルおよびポリビニルアルコール

の粘度分子量関係

第 4 報 ポリ酶酸ビニルの光散乱および粘度

测定結果の三, 三の考察

(1959 年 5 月 12 日受理)

松本昌-**大柳康治*

\begin{abstract}
要 旨 前報”で測定して得た末分別低重合率ポリ酶酸ビニルの理想溶媒(メチルイソプロピルケトン $72.7 \mathrm{vol} \% \sim \mathrm{n}$ ヘファタン $27.3 \mathrm{vol} \%, 30^{\circ} \mathrm{C}$ ) および非理想溶媒(アセトン,メチルエチルケトンおよびメタ)ー

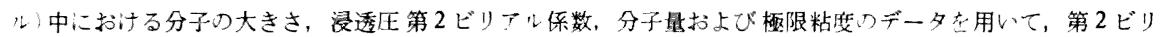

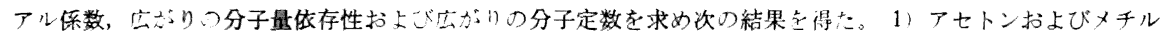
エチルケトン溶液中での重量平均の分子の伀ボり (radius of gyration) 〈

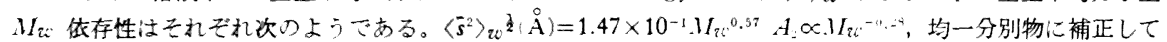
$\left(s^{2}\right)=1.41 \times 10^{-1} M^{0.57}$ である。これからアセトンおよびメチルエチルケトン系のつ effective bond length

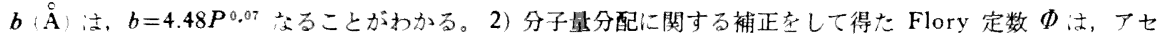

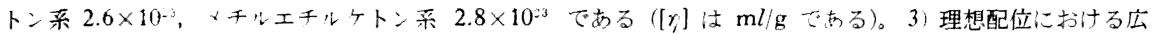

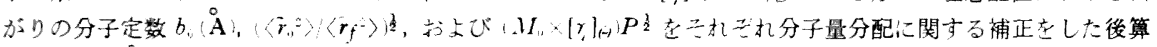

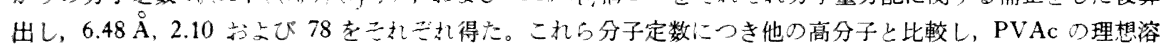

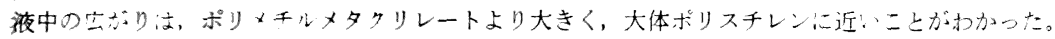

\section{1. 緒言}

溶液中に㧍ける高分子の形態は，溶媒および温度に依 存するが, Flory $の \Theta$ 点ではポリマー分子は, 排除体 積効果に基くセク゚メント間の遠距㒕効果のない形態をと ると考えられ，日点での測定は，希薄溶液の諸性質に及 ぽすポリマーの分子形態の效哭吉比較するのに重要な手 段となっている。

本報では，さき汇测完して得た低重合率のポリ酢酸ビ ニル (PVAc)の理想溶郕(メチルイソプロピルケトン〜 n一ヘプタン混合)妨よび非理想溶剂(アさトン,メチルニ チルケトンおよびメタノール)中に斿ける分子の大きき, 極限粘度数，浸透压第 2 ビリアル倸数㧍よび分子量のデ 一ダを用いて，第 2 ピリアル俰数，広がりの分子量依 存性, Flory 定数および広がり口分子定数を求心圷。

\section{2. 実験方法および実験結果}

詳細は第 3 報で述へただ，大要は次の上うである。

\section{1 試 料}

\section{1.1 PVAc}

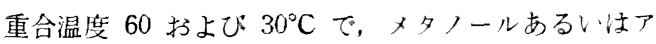
セトン溶剂系で重合し, 重合萃 100 ，以下の PVAc を 合成した。

\section{1 .2 溶 斉}

試薬一級品のアセトン, メチルエチルケトン(MEK),

* 倉整レイヨン株式会社研究所(倉䑤市酒津)
メタノール, メチルイソプロピルケトン (MIPK), n-へ プタンをいずれも常法により指帮，蒸留した。

\section{2 粘度测定}

[ク]の測定は, $30 \pm 0.03^{\circ} \mathrm{C}$ で行なった。Flory 溶剤( 溶剂)として, MIPK 72.7 vol $\%\left(30^{\circ} \mathrm{C}\right)$ を用いた ${ }^{2)}$ 。

\section{3 光散乱測定}

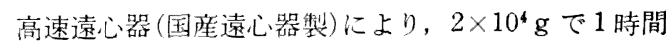
遠心し，さらにたラフィいタ一を用いてロ過した溶液に つい, $30^{\circ} \sim 140^{\circ}$ の 16 個の角度で散乱強度を測定し た。使用波上流 $4360 \AA$ であり，Zimm 法で解析した。

\section{4 実験 結果}

実験結果は第 3 報で方したから省略する。

\section{3. 考察}

\section{1 光散乱测定テーータの考察}

\section{1 .1 広がりの分子量依存性}

光散乱測定から得た分子の広がり(radius of gyration) $\left\langle\bar{s}^{2}\right\rangle_{g}$ は，(1)式に示すように定義される。

$$
\left\langle\bar{s}^{2}\right\rangle_{g}=\left(\int_{0}^{\infty} \bar{s}_{t}{ }^{2} \cdot M \cdot f(M) d M\right) /\left(\int_{0}^{\infty} M \cdot f(M) d M\right)
$$

ここで $f(M)$ は分子量の分布関数， $\bar{s}_{i}{ }^{2}$ は均一分别物 の分子の広がりを示す。ザはントの分布が, ガウス分 布であると仮定すれば， $\left\langle\bar{s}^{2}\right\rangle_{g}$ は $z$ 平均量を与える。

また，一般に〈 $\left.\tilde{s}^{2}\right\rangle$ の代りに，分子雨端間自乘平均距 
䧴 $\left\langle\tilde{r}^{2}\right\rangle$ がよく用いられている。 $\Theta$ 点では $\left\langle\bar{r}^{2}\right\rangle=6\left\langle\bar{s}^{2}\right\rangle$ と

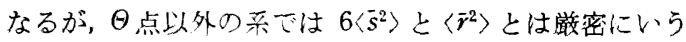
と等し〈ないる。そこで，ここでは〈福〉を用いることに する。

$\left\langle\bar{s}^{2}\right\rangle$ の分子量依存性を求める際，他の研究者らのデー 夕は重量で表わされているから，これと比較するため重 量平均を用いる。この㣽め光散乱の角度変化の測定から 得た $\left\langle\bar{s}^{2}\right\rangle_{g}$ を, 重量平均の広がり $\left\langle\bar{s}^{2}\right\rangle_{w}$ に換算する必要 がある。

完全に分子星け均一な試料で, $\bar{s}_{l}{ }^{2}=A M_{i}{ }^{1+\beta},\left[\gamma_{i}\right]_{i}=$ $K M_{i}^{n},[r]_{i}=6: \Phi\left(\bar{s}_{1}^{2},: M_{i}\right.$ 上する。ここで $M_{i}$ は均一試 料の分子量, $\bar{s}_{i}{ }^{2}$ はこの radius of gyration の自乗平均, $[\eta]_{i}$ 汇極限粘度数であり， Фは Flory の定数である。そ れぞれの関係は上く知られた関係であるから説明は省略 する。Flory の $\Theta$ 点では、, $\hat{\beta}=0$ であり $\bar{s}_{l}{ }^{2}=A M_{i}$ であ るが，非理想溶媒采では采まり分子のふくれによりふな る補正がいる。前述の三つの関倸が同時に成立するとす 机代， $1+3,3=2 n$ でなけ机は妨らな。

ここで分子量分配のある試料を考えて，その分配関数 を第3 報で述べた形式のもの应收定寸ると（1）式を用い $\tau$

$$
\left\langle\vec{s}^{2}\right\rangle_{w}=\left\langle\vec{s}^{2}\right\rangle_{g}(1+h, 2+h+, \hat{s})
$$

が容易に得られ*, $1+3 ;=2 n$ を使うと

$$
\left\langle\bar{s}^{2}\right\rangle_{w}=\left\langle\bar{s}^{2}\right\rangle_{g}\left(1+h /\left(\frac{5}{3}+\frac{2 n}{3}+h\right)\right.
$$

と書き直せる。

nの值は，アセトンおよぴ×チルエチルケトン系でい ずれもほほ 0.72 なるこよは第 3 報でわかった。またわ れわれの用いている低重台桲分別ポり酷酸ビニルで は， $M_{v} / M_{n}=2$ 灰ることがわかった。これは分子量分 配の幅を示すパラメーターんがること京す。

アセトンおよびメチルエチルケトン系で測定して得た $\left\langle\vec{s}^{2}\right\rangle_{g}$ を， $n=0.72, h=1.0$ を用:てて $\left(2 \gamma^{\prime}\right.$ 式により換算し て得た $\left\langle\bar{s}^{2}\right\rangle_{w}$ と, 重量平均行子量 $M_{i c}$ の関釈を耐対数で

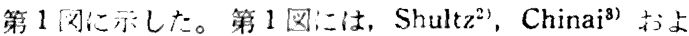
び Patat)らのデータもともに示した。ここで得たデー タは, Patat のデータ除いて, 他の研究者らのデー夕 とよく一致し，一つの直線上によくのっていることが認

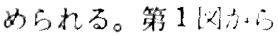

$$
\left\langle\bar{s}^{2}\right\rangle_{u^{2}}=1.47 \cdot 10^{-1} \cdot H_{l_{i}}^{0.5 i}(\AA)
$$

なる関係が得られら。 $1+3 ;=2 n$ 在使えば $n=0.72$ から

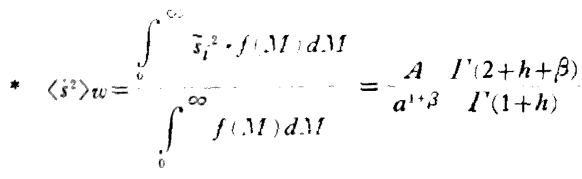

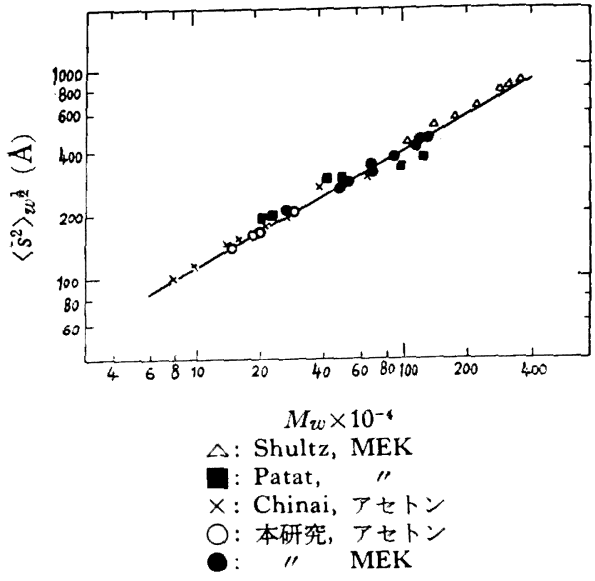

第1図 PVAC 分子の広がり $\left\langle\bar{s}^{2}\right\rangle_{w^{2}}$ と $M_{w}$ の関係(両対数)

$\beta=0.147$ となり (3) 式の指数は 0.574 上なるべきであり， 実験誤差の䇛囲でよく一致している。Patat の得た関倸 は，(3)式の関倸と異なり $\left\langle\bar{s}^{2}\right\rangle u^{b} \propto M_{w}{ }^{0.50}$ であるが，第 3 報で述へた の関保は異常に小さいと考えられる。

完全に均一分別物で $\bar{s}_{t}{ }^{2}=A M_{i}{ }^{1+\beta}$ として, ここに仮定 した分配関数を使って不均一試料の広がり $\left\langle\bar{s}^{2}\right\rangle_{w}$ を求为 ると

$$
\left\langle\bar{s}^{2}\right\rangle_{w}=\left(A / a^{1+\beta}\right)[\Gamma(2+h+\beta) / \Gamma(1+h)]
$$

となり,(4)式に $M_{w}=(1+h) / a$ を使って

$$
\left\langle\tilde{s}^{2}\right\rangle_{w}=A \underset{(1+h)^{1+\beta} \Gamma(1+h)^{\Gamma}}{\Gamma(2+h+\beta)} M_{w^{1+\beta}}
$$

なる関倸が得られる。すなわち

$$
\begin{aligned}
& A^{\prime} \\
& A^{\prime}
\end{aligned}=\begin{gathered}
\Gamma(2+h+\beta) \\
(1+h)^{1+\beta} \Gamma(1+h)
\end{gathered}
$$

こなる。ここで用いた試料では， $\left(M_{w} / M_{n}\right)=2, \beta=0.14$ であるから， $A^{\prime} / A=\Gamma(3.14) / 2^{1.14}=1.04$ となり

$$
A=0.96 A^{\prime}
$$

が成立し， $A$ と $A^{\prime}$ はほとんど等しいことがわかる。す なわち(3) 式は，完全均一物にも大体適用できることが わかる。(7)を使って完全均一物の分子の広がりは

$$
\left(\bar{s}^{2}\right)^{2}=1.41 \times 10^{-1} M^{0.57} \quad(\AA)
$$

で与えられる。

3.1.2 良溶媒系における分子の有効結合長 (effective bond length) $b(\AA)$

近距雄相互作用のみを考えると 


$$
\frac{\left\langle\bar{r}^{2}\right\rangle}{P l^{2}}=\frac{1+\cos \theta}{1-\cos \Theta} \cdot \frac{1+(\cos \psi)_{a v}}{1-(\cos \psi)_{a r}} \equiv \frac{b^{2}}{l^{2}}
$$

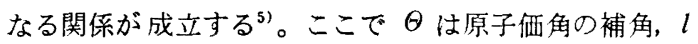
はモノマー単位の結合の長さ, 〈 $\left.\bar{r}^{2}\right\rangle$ は両端間距雞の自 乗平均, $P$ は重合度， 次の結合との間の角をそれぞれ示す。自由回転の場合は $(\cos \psi)_{a v}=0$ である。この $(8)$ 式は，Pが十分大きく， $(\cos \psi)_{a v}$ が 1 に近くないほど良い結果を与える近似式 とされている。(8)式を用いて $b(\hat{A})$ を求めるには, ア七 トンまたはメチルエチルケトン系での完全分別物に対す る〈 $\left.\tilde{r}^{2}\right\rangle$ と $P$ の関俰が明らかであることが必要である。 $\langle 3)^{\prime}$ 式で完全均一分別試料の $\left\langle\bar{s}^{2}\right\rangle$ 之分子量との関係が わかったから，この関係を(8) 式に代入して単位重合度あ たりの有効結合長 $b(\AA) を$

$$
b=\left\langle\bar{r}^{2}\right\rangle \frac{1}{2} / P^{2}=6 \frac{1}{2}\left\langle\bar{s}^{2}\right\rangle \frac{1}{2} / P^{2}=4.48 P^{0.07}
$$

となる。これから種々の重合度のものの単位重合度あた クの有効結合長を求めると

$$
\begin{array}{ll}
P=10^{3} & b=7.26 \AA \\
P=10^{4} & b=8.55 \AA \\
P=10^{5} & b=10.05 \AA
\end{array}
$$

となる。これは $\left\langle\bar{s}^{2}\right\rangle=A \times M^{1+\beta}$ の,$\hat{\zeta}>0$ であるから， 重合度とともに有効結合長が增すのは当然である。

3.1.3 $A_{2}$ の分子量依存性, $A_{2}$ と他の測定量との関係 $A_{2}$ に及ぼす分子量分配の影響については理論的にも 実験的にも決定的な結論に到達してないようである。た だ光散乱法で求まる $A_{2}$ は, 浸透圧法で求められる $A_{2}$ に比べて分子量分配の影響が小さく, $A_{2}$ 決定法として前 者の方が良いといわれているあ。光散乱法で求められる $A_{2}$ の精度についてはなおかなり問題があり，われわれ の得た $A_{2}$ もとれだけの精度があるかは今後の唡討にま ちたいがここでは一応得た結果を信頼して考察をすす める。

まず $A_{2}$ の分子量依存性を求めた。第 2 図に $A_{2} \sim M_{w}$ の関係を両対数で Shultz ${ }^{2)}$, Chinai ${ }^{31}$ らのデータととも に図示した。図にみるようにわれわれの結果と各研究者

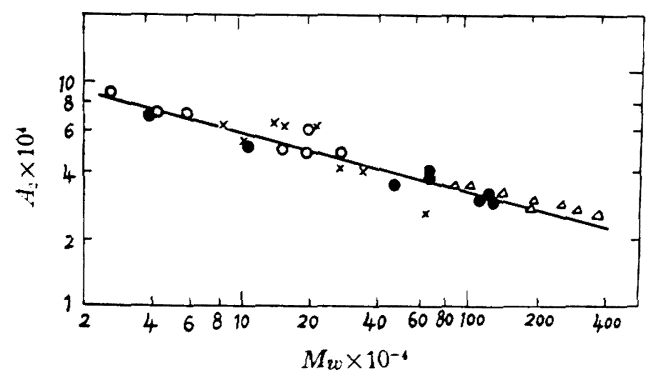

$\triangle:$ Shultz, MEK,

: 本研究, MEK

X: Chinai, アセトン, $\bigcirc$ : 本研究, アセトン

第 2 図 $A_{2}$ 上 $M_{w}$ の関倸 (両対数)
の結果は大体よく一致し, 両対数で一直線上にほぼのり, $A_{2} \propto M_{w}{ }^{-0.28}$ が認められる。Shultz あるいは Chinai らの結果はかなりシャープな分別物での結果であり，わ れわれの結果は不均一性, $M_{w} / M_{n}=2$ なる分子量分配物 での結果である。これらの結果が $\log A_{2} \sim \log M_{w}$ の関 倸で, ほぼ一つの直線で表らわされることは光散乱で求 められた $A_{2}$ と $M_{v}$ の関倸は, この程度の不均一性の試 料ではあまりその影響を受けないといらことかもしれな い。

Shultz が行なったように $\left(A_{2} \times M_{w}^{2}\right) /\left\langle\bar{r}^{2}\right\rangle$ ，および $\left(A_{2}\right.$ $\left.\times M_{w}\right) /\left[r_{1}\right]$ を求めると, 多少㖔つくが分子量に無関倸 にほぼ一定となり，その平均值はア七トンまたは $\mathrm{MEK}$ 系で, 前者で $3.63 \times 10^{23}$, 後者で 1.45 (ただし [ク] は $\mathrm{m} l$ l $\mathrm{g}$ 単位)となり文献值上大体一致する。

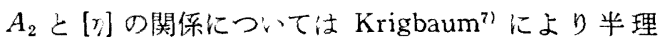
論式

$$
[\eta]-[\eta] \theta=3(134 / 105)(3 / 2 \pi) 2\left(\Phi / N_{A}\right) A_{2} M_{w}
$$

が得られており，これとよく似た関倸は倉田，山川氏ら の理論 ${ }^{8)}$ から $\Theta$ 溶液に近い溶液系では

$$
\begin{aligned}
& \left([\gamma] /[\gamma]_{\theta}\right)-1=\left(0.488 A_{2} M /[\gamma] \Theta\right) \\
& \quad+0.155\left\{2.865-\hat{\gamma}^{\prime}(X)\right\}\left(A_{2} M /\left[r_{\zeta}\right]_{\theta}\right)^{2}+\cdots \cdots
\end{aligned}
$$

が得られる。ここで $\beta^{\prime}(X)=p^{\prime}(X) / p(X)$ であり, $p^{\prime}(X)$ および $p(X)$ の意味は原論文を参照されたい。(10)は均 一な完全フラクションにつ、ての関倸である。右辺の第 2 項の 2.865 - $\beta^{\prime}(X)$ はかなり小さい值となり， $([\gamma] /[\eta] \theta)$ -1 と $\left(A_{2} \times M\right) /[\eta]_{\Theta}$ の直缐関倸は, 不良溶媒中ではか なり広範囲に成立しそらである。(10)の第 2 項の寄与が 正か負かは定説がなく, 倉田氏らの理論では正, OrofinoFlory の理論9) では負となる。われわれの得た結果は良 溶媒系での値であり，しかも $\left(A_{2} \times M_{w}\right) /[\gamma] \theta>1$ である から，(10)の第 2 項を無視できるほど十分に 2.865 一采 $(X)$ が小さいかどうか疑問であり, まず $(10)$ は理論 的には適用できないが，一応強引にあてはめて $[\eta] /[\eta]_{\theta}$ を $\left(A_{2} \times M_{w}\right) /\left[r_{i}\right] \theta$ に対して図示すると第 3 図に示した ようである。(10)が要求するように， $(1,0)$ をよぎる直線

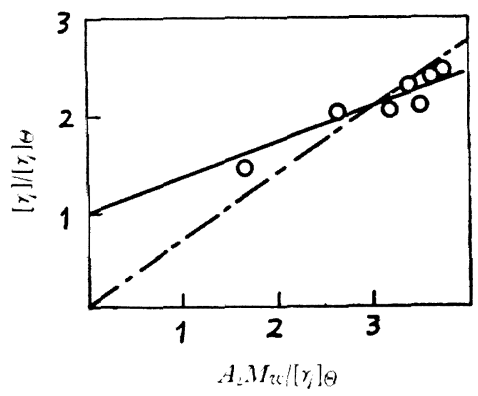

第3 図 PVAc $M$ MEK 采の $[\gamma]\left\llcorner A_{2}\right.$ の関倸 
上(第 3 図実線)に大体のるといえる。この傾斜は $0.3 \sim$ 0.4 であり(10)の要求する值より若干小さいが,ほぼ同じ オーダーである。

良溶媒系の Orofino-Flory 理論によれば

$$
A_{2} M /[r]=\text { Univ. Const. } \ln \left\{1+{ }_{2}{ }^{\pi}\left(\alpha^{2}-1\right)\right\}(11)
$$

となり，良溶媒采では分子量による $\alpha$ 違いは小さいの で対数項は一定上すれば, $\left(A_{2} \cdot M\right) /[r]$ は近似的に一定 值を与える。このここは第 3 図で原点を通る直線（第 3 罒鎖線）にのることを意味する。第 3 図だけの結果から は，いずれの直線が適合するか区別ができないようであ り，また傾斜の理論值上赛駼值上の差を両者ほほ同じよ うであり、これだけの実験からは、いずれが良いかわか らない。

\subsection{Flory 理論による粘度データの考察}

最近, 价田, 山川両氏日) らは, Flory 理論を排除体積 勃果と溶媒の浸及远及の效果在い机て考察し, Flory 式の形のま去， $[\gamma]=\Phi \times 6 ! \times / \bar{s}^{2} / 3 / M$ で定義される Flory 定数 $\Phi$ は，溶剤，温度などに依存することを明ら かにされた。しかしその理論でも述べられているよう 心, 溶剂, 温度一定で測定して得た場合の $\Phi$ は大体一定 とみなされる。そこでここでは，一忘従涑よりよく用い られている Flory 理論により実娩結果を考察する。

\section{2.1 Flory 定数, $\Phi$}

Floryにより示された関倸式

$$
[r]=6 \geq \cdot \Phi\left\langle\bar{s}^{2}\right\rangle \mathbf{z} / M
$$

により Flory 定数 $\Phi か ゙\left\langle\bar{s}^{2}\right\rangle$ と $M$ から求まる。しかし

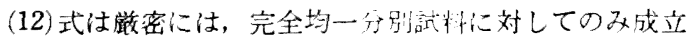
する。
本研究で測定した試料の分配は， $M_{w} / M_{n}=2$ であるか らФを求めるには，分子量分配に関する補正が必要であ る。

この補正については別報に述べるが，3.1.1 拈よび 3.1 .2 で処理したのと全く同じよ5に，第 3 報で述べた 分配関数を用いてこの関倸を数值計算することができ る。

見かけの定数 $\Phi^{\prime}{ }^{\prime}$ と均一分別試料に対する $\Phi$ との間に

$$
\Phi_{g^{\prime}} \mid \Phi=\left\{\begin{array}{c}
\Gamma(h+2) \\
\Gamma(3+h+\beta)
\end{array}\right\}^{\nexists(1+h+n)} \frac{\Gamma(1+h)}{\Gamma(1+h)}
$$

なる関係が得られる。ここに $\Phi_{g}{ }^{\prime}$ は, ある分配をもった 試料について，光散乱掞よび粘度測定による $M_{w},\left\langle\bar{s}^{2}\right\rangle_{g}$ および $[r]$ を用いて算出される見かけの定数を示す。第 1 表に実験で得た $M_{w},\langle\vec{s}\rangle_{g},[\eta]$ を使って(12)式から得 た見かけの定数 $\Phi_{g^{\prime}}$ と，(13) 式により均一物のそれへと 補正して得た $\Phi$ それぞれ示した。なお(2)式により $\left\langle\bar{s}^{2}\right\rangle_{g}$ を $\left\langle\bar{s}^{2}\right\rangle_{w}$ に換算し, $\left\langle\bar{s}^{2}\right\rangle_{w},\left[\gamma_{]}\right], M_{w}$ を使って(12) 式から算出して得た $\Phi_{w}{ }^{\prime}$ 子第 1 表に示した。いずれの Flory 定数も, 分子量に無関倸にほぼ一定であり, 完全 均一分別物へと補正した $\Phi$ は, アセトン采, メチルエチ ルケトン采でそれぞれ平均 2.58 および $2.76 \times 10^{23}$ ([ク] の単位は $\mathrm{m} l / \mathrm{g}$ )である。

この值はまたすでに求めた完全均一物での関倸 $\left\langle\bar{s}^{2}\right\rangle=$ $A M^{1+\beta},[r]=K M^{n}$ の $A=1.99 \times 10^{-18}$ および $K=1.08$ $\times 10^{-2}, 1.13 \times 10^{-2}$ を使って $\Phi=K /(63 A$ 录 $)$ を求めると, 2.56 および $2.72 \times 10^{23}$ となり，上記の值とよく一致し た。このようにして得た定数 $\Phi$ は, Flory らが求めた值 $2.1 \sim 2.5 \times 10^{23}$ より若干大きく，倉田，山川両氏らの最

\begin{tabular}{|c|c|c|c|c|c|}
\hline \multirow{2}{*}{ 試料番号 } & 得 & \multirow{2}{*}{$M_{w} \times 10^{-4}$} & \multicolumn{3}{|c|}{ Flory 定数 } \\
\hline & 剂 & & $\left.\Phi_{g^{\prime}} \times 10^{-28} *\right)$ & $\left.\Phi_{w^{\prime}} \times 10^{-23} * *\right)$ & $\left.\Phi \times 10^{-23} * * *\right)$ \\
\hline $\mathrm{H}-4$ & メチルエチルケトン & 127 & 1.25 & 2.44 & 2.76 \\
\hline $\mathrm{H}-5$ & " & 121 & 1.22 & 2.36 & 2.68 \\
\hline $\mathrm{H}-6$ & $"$ & 114 & 1.33 & 2.58 & 2.94 \\
\hline OS-12 & $"$ & 77.3 & 1.29 & 2.50 & 2.84 \\
\hline $\mathrm{H}-8$ & $"$ & 69.5 & 1.26 & 2.44 & 2.76 \\
\hline $6-0$ & " & 69.0 & 1.20 & 2.32 & 2.64 \\
\hline OS -16 & " & 54.5 & 1.27 & 2.46 & 2.80 \\
\hline $6-1$ & " & 48.5 & 1.15 & 2.24 & 2.53 \\
\hline A-17 & $"$ & 47.2 & 1.32 & 2.55 & 2.90 \\
\hline $6-3$ & " & 19.7 & 1.27 & 2.46 & 2.80 \\
\hline
\end{tabular}
近得た漸近值 $2.87 \times 10^{23}$ に近( ${ }^{8)}$ 。

第 1 表 光散乱および粘度測定による Flory 定数 


\begin{tabular}{|c|c|c|c|c|c|}
\hline $\mathrm{H}-7$ & アセトン & 84.5 & 1.22 & 2.36 & 2.68 \\
\hline $5-2$ & " & 71.5 & 1.13 & 2.18 & 2.48 \\
\hline 5-1 & " & 69.6 & 1.16 & 2.28 & 2.55 \\
\hline $6-2$ & " & 28.6 & 1.15 & 2.24 & 2.53 \\
\hline $6-3$ & " & 20.0 & 1.26 & 2.44 & 2.77 \\
\hline \multirow[t]{2}{*}{$6-6$} & " & 15.3 & 1.13 & 2.18 & 2.48 \\
\hline & & 平 & & & 2.58 \\
\hline
\end{tabular}

\section{2.2 Flory-Fox 理論の検討}

Flory-Fox の理論によれば，(12) 式は次つように書き 直せる。

$$
[\eta]=\Phi\left(\left\langle\bar{r}_{0}{ }^{2}\right\rangle / M\right)^{2} M^{2} \alpha^{3}=K M^{2} \alpha^{3}
$$

ここで〈 $\left.\bar{r}_{0}{ }^{2}\right\rangle$ は $\theta$ 点での分子両端間自乗平均距離であ る。

$T=\theta$ では $\alpha=1.0$ であるから, (14)式は

$$
[r] \theta=K M^{2}
$$

である。これに Flory-Fox の関倸

$$
\alpha^{5}-\alpha^{3}=2 C_{M} M_{1} 1-\Theta_{i} T, M=C_{T} M^{1}
$$

を用いれば

$$
[r]^{3} M M^{3}=K^{3}+C_{T} K^{\mathfrak{3}} M /[r]
$$

となる。[r]と $M$ を用いて(14)，(15)式での定数 $K$ およ び(16)式での定数 $C_{T}$ が求められる。

アセトン，メタノールおよび MIPK-nーヘプタン混合 溶剂 $\left(30^{\circ} \mathrm{C}, \theta\right.$ 点) 系などの $[r]$ 上分子量の測定值 ${ }^{1)}$ を, 完 全江均一な分別試料のそれらに補正し，第 4 図に(17)式 の関倸を示した。メチルエチルケトン采の[ク]はアア七

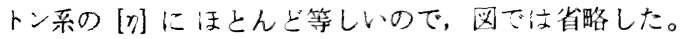
(17)式の要求するように，それぞれ遖缐上にのっている ことが，第 4 図で明らかである。たたし $M /[$ 凤 が 1500 以下のデータがないため, この直線が $M /[r] \rightarrow 0$ まで成

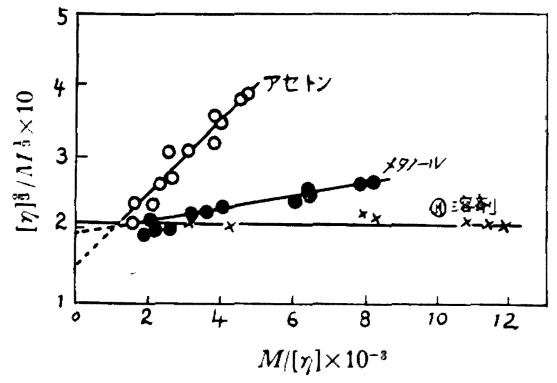

第 4 図 $[y]$ [ $/ M^{\natural}$ と $M /[y]$ の関係
立しているのか，あるいは $M /[\gamma]$ の小さいところで曲 るのかはこれだけの実験点からは不明である。いまかり にこの值線がそれぞれ $M /[\eta] \rightarrow 0$ まで成立するとすれ

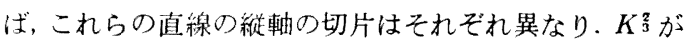
異なることになる。アセトン系扩よびメタノール系の $K$ は,ここで用いた $\Theta$ 溶剤采のそれに比べてそれぞれ 40\% および $10 \%$ 小さい值が得られる。後者はともかく，前 者の差は明らかに実験誤差以上の差である。

このような $K$ の差は, 同一分子量でも溶剤により $[\eta] \Theta$ に差があることになる。セルロース誘導体のように剛性 度の大きい高分子では，その $[\gamma] \theta$ は温度および溶郕に 著しく依存する ${ }^{12}$ 例もあるが, PVAcのようにかなり屈

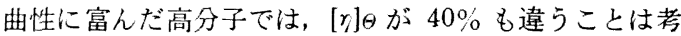
えにくい。このように，Kに差の現われたのは，あるい は第 4 図で点線部分まで直線を外挿したことに誤りがあ るのかも知れない。すなわち良溶郕系では， $C_{T}$ は一定 でなく分子量の小さいところで顕著に変化し，ある程度 以上分子量が大きくなって一定となるのかも知れない。 このような考え方をすると, ア七トン采の場合もメ夕， ールあるいはここで用いた $\Theta$ 溶戍采とほぼ同じ $K$ から 出発しているとも考えられる。そこでアセトン采での基 準となる $[\gamma] \Theta$ として，ここで用いた $\Theta$ 溶剂系の $[\gamma] \Theta$ を 用い，すなわち $[r] \theta$ は溶剤に無関倸に一定と考え， $[r] /$ [r] $\Leftrightarrow=a^{3}$ として $\left(\alpha^{5}-\alpha^{3}\right) / M$ を $\ln M$ に対して図示す ると第 5 図のごとくなる。

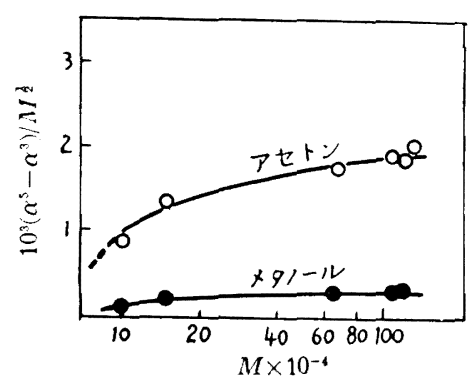

第 5 図 $\left(a^{5}-a^{3}\right) / M^{1} \leq \log M$ の関倸 
アセトン系では $\left(\alpha^{5}-\alpha^{3}\right) / M \frac{1}{2}$ は一定でなく, 分子量 の小さいところで急増し，その後は漸次増大している。 このことは， $C_{T}$ が一定でないことを示すものであろう。

以上のごとく，もし $K$ が各系で異なるとすれば実験結 果は, Elory-Fox の関係(17)で説明できる。しかし，そ れにしては $K$ はあまりにも違いすぎる。また $K$ を溶剂 により差がないとすれば, Flory-Foxの理諭は成立せず, C は一定でないとせ柿ならない。いずれの解釈が良 いかは、これだけでは不明である。

倉田，山川両氏らの鎖状高分子の形態に関する理 論 ${ }^{81}$ によれば， $\Theta$ 溶剤に近い状態では

$$
\alpha^{2}=\left\langle\bar{s}^{2}\right\rangle /\left\langle\bar{s}_{0}^{2}\right\rangle=1+(134 / 105)(6 / \pi)^{2}(b / a)^{3}(1-\Theta / T) N^{2}
$$

なる関係式が成立する。ここに表われる記号の意味は， 原報を参照されたい。また酉田氏らの極限粘度の理論8 を使えば

$$
[\eta] /\left[r_{i}\right]_{\theta}=\alpha^{2.43}
$$

となる。われわれの実験では $\Theta$ 点での光散乱の㬰験を 久いているので, $(18,19)$ 式の吟味ができない。しかし 今, (19) 式を仮定して極限粘度の比から $\alpha$ を求め, $\left(\alpha^{2}-\right.$ 1)を $M^{\frac{1}{2}}$ にプロットすると(18)式が要求するように，原 点を通る直線上によくのる(図は省略する)。ただしこの
場合 $\alpha^{3}=\left([\eta] /[\eta]_{\theta}\right)$ を使って $\alpha$ を求めてもほぼ同様な関 倸が認められ，この実験だけから(18)式と Flory 式とい ずれがよくあらか区別することはできない。

\section{2.3 理想配位における広がり}

ポリマー分子銧の広がりを示す分子定数として， $\left(\tilde{r}_{0}{ }^{2}\right)$ $\left.\bar{r}_{f}^{2}\right)^{2}, b_{0}=\left(\bar{r}_{0}^{2} / P\right)^{2}$ および $\left(M_{0}[\gamma] \theta\right) / P^{\frac{1}{2}}$ なる量が用いら れる。ここに $\left(\bar{r}_{f}^{2}\right)^{\frac{1}{2}}$ は, 鎖の単結合の自由回転を仮定し $l_{0}=1.54 \AA ， \Theta=109.5^{\circ}$ として計算される分子両端間自乗 根距離， $M_{0}$ は一鎖長単位の分子量をそれぞれ示す。

これらの実験的諸量のらち, $\left(\bar{r}_{0}^{2}\right)$ は $\Theta$ 点の光散乱測 定から求めることが必要である。しかしここではその測 定を行なっていないので, Flory 定数を仮定して (15) 式 の定数 $K=9.79 \times 10^{-2}$ より*これら分子定数を算出する ことにした。

倉田氏らの理論によれば ${ }^{8)}, \Theta$ 点では Flory 定数 $\Phi$ は $2.87 \times 10^{28}$ である。そこで(15) 式で得た定数 $K$, および 他の高分子について得られている $K$ より， $\Phi=2.87 \times 10^{28}$ としてこれら分子定数を算出し比較した**。その結果を 第 2 表に示した。

なお Chinai 一派によるポリメタタリレート誘導体に ついては, 光散乱測定による值が得られているからその 值も第 2 表に示した。

$$
\text { 次に }\left(M_{0}<[r]_{H} / P^{\frac{1}{2}}\right) \text { を求めた。(8)式を(14) 式に代入 }
$$

第 2 表 理想配位における広がりの分子定数

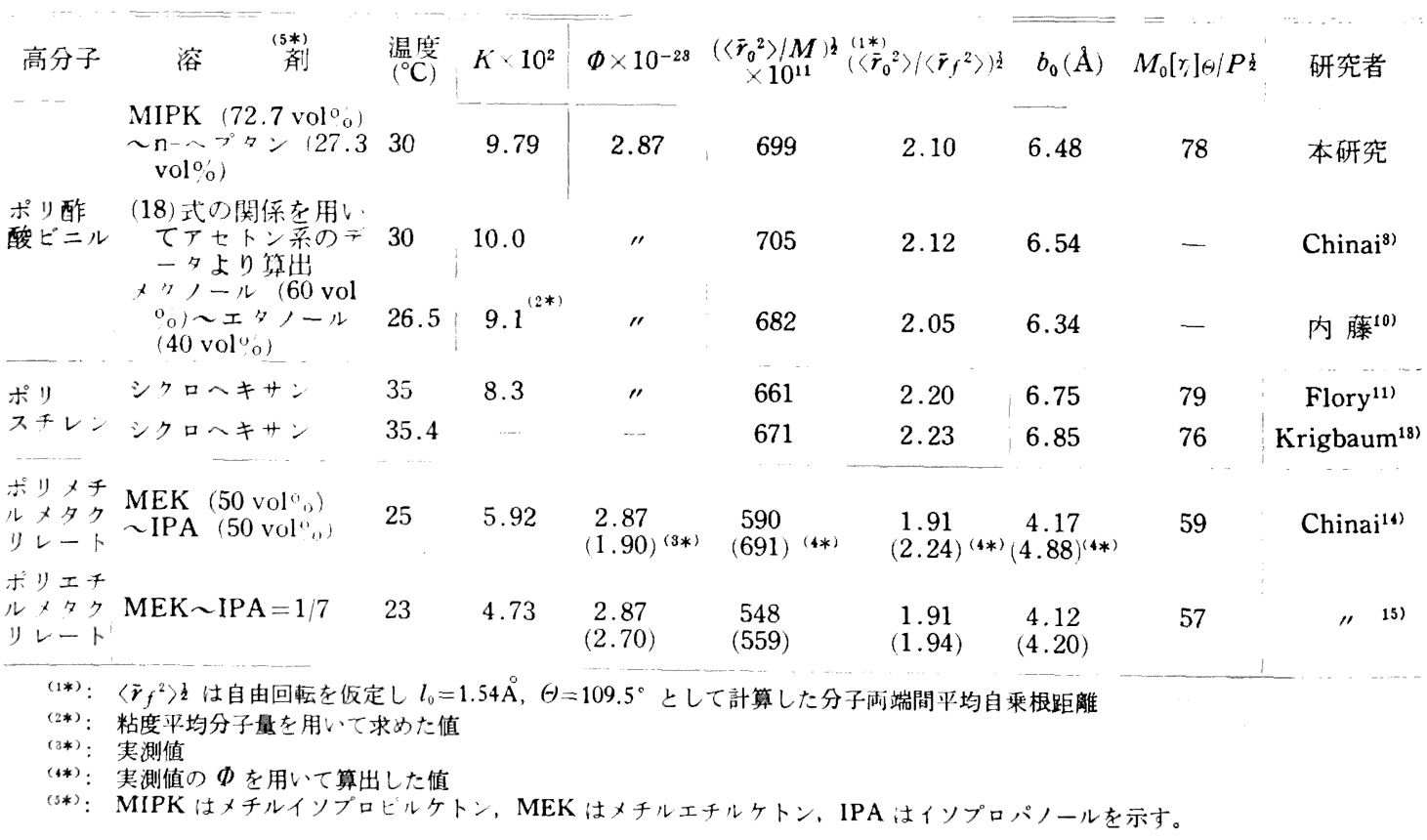

* 第3 報で得た值より分子虽分配に関する補正をして完全均一分別鸹料に対する値を算出した。

***他のデータは $D=2.1 \sim 2.5 \times 10^{23}$ が使われているが，われわれのここでの計算上比較するため， $\Phi=2.87 \times 10^{23}$ で計算し直した。 
すれば $\left(M_{0} \times[\eta]_{\theta} / P \hat{k}\right)=\Phi \times\left(b_{0}{ }^{3}\right)$ と示されるように，こ の量は有効結合長 $b_{0}(\AA)$ の関数であり,この值の大小は ポリマー分子の stiffness の程度を表わす。前章で得た $\theta$ 点での $[\eta]_{\theta} \sim M_{w}$ 関係を, 完全均一物へと補正して $[\eta]_{\theta}=9.79 \times 10^{-2} M^{0.50}$ が得られるから， $\Phi\left(b_{0}{ }^{3}\right)=M_{0^{2}} \times$ $9.79 \times 10^{-2}=78$ を得る。

第 2 表に示したように, PVAc の理想配位における有 効結合長 $b_{0}(\AA)$ は約 $6.5 \AA$ であり,また自由回転ができ るとした理論值より約 2.1 倍大きいことがわかる。

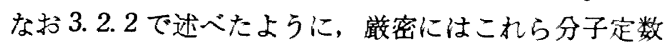
は, 温度, 溶剤にも依存すると考えられるが, 実駼誤差 を考慮するとこここで得た值は他の研究者によりPVAc について得られている値と一致し，その差異はないと考 えて良いであろう。

また第 2 表に示した他の高分子のデータと比較すれ ば,ここに示したポリマー分子の stiffness はポリスチ レン>ポリ酢酸ビニル>ポリメチルメタクリレート>ポ リエチルメタクリレートの順であることが認められる。 なお PVAc は, 大体ポリスチレンと同じ程度であるこ とがわかる。ただし、これらは普通の重台条件で得られ た各高分子に関するデータであり, 最近注目されて来て いる立体特異性高分子については全く別問題であるかも しれず汭，これは今後の興味ある課題である。

付 記：浸透圧第 2 ビリアル倸数上極限粘度, 分子量の 関保につきご教示をいただいた京都大学倉田道夫助教授, 本研 究の発表を許可された会社当局に感謝します。実験に協力され た田中寿氏, 山本良盛氏らに謝意を表明します。(本報告の一 部は, 高分子研究発表会 1958 年11月於京都)で発表した，

\section{文献}

1）大柳康治, 松本昌一：高化, 16, 296(1959)；松本 昌一, 大柳康治：高化, 17, 1 (1960)

2) A.R. Shultz: J. Am. Chem. Soc., 76, 3422 (1954)

3) S.N. Chinai, P.C. Scherand and D.W. Levi : J. Polym. Sci., 17, 117 (1955)

4) H.G. Elias and F. Patat: J. Polym. Sci., 29, $141(1958)$

5) P.J. Flory: "Principles of Polymer Chemistry" 第 10 章

6)a）尾山外茂男：日化年会 (於東京, 1958年 4月)

b) C. Jen-Yuan, S. Liang-Ho and Y. Shih-Chieu: J. Polym. Sci., 29, 117 (1958)

7) W.R. Krigbaum: J. Polym. Sci., 18, 315(1955); ibid., 28, 213(1958)

8) M. Kurata and H. Yamakawa: J. Chem. Phys., 28, 785(1959); ibid., 29, 311 (1959)

9) T.A. Orofino and P.J. Flory: J. Chem. Phys., 26, 1067 (1957)

10）内藤龍之介：高化, 16, 7 (1959)

11) P. J. Flory: "Principles of Polymer Chemistry" 559

12) P.J. Flory, O.K. Kapur and D.K. Carpenter: J. Polym. Sci., 27, 231 (1958)

13) W.R. Krigbaum and D.K. Carpenter: J. Phys. Chem., 59, 1116(1955)

14) S.N. Chinai, J.D. Matlack, A.L. Resnick and R. J. Samuels: J. Polym. Sci., 17, 391 (1955); S.N. Chinai and C.W. Bondurant: J. Polym. Sci., 22, 555(1956)

15) S.N. Chinai and R. J. Samuels: J. Polym. Sci., 19, 463(1956)

16) W.R. Krigbaum and D.K. Carpenter: J. Phys. Chem., 62, 1586 (1958)

\title{
Viscosity-Molecular Weight Relationships of Poly-(Vinyl Acetate) and Poly-(Vinyl Alcohol)
}

\section{Some Discussions on the data of Light Scattering and Viscosity Measurements Poly-(Vinyl Acetate) \\ By Masakazu Matsumoto* and Yasuzi Ohyanagi*}

\begin{abstract}
The results of the light scattering and viscosity measurements with poly-(vinyl acetate) had been reported in the previous papers Part II and III. Some considerations were made on the radius of gyration, second virial coefficient, Flory's constant and molecular constant of polymer dimension on the basis of the results. The relationships between weight average root-mean square of molecular radius $\left\langle\bar{s}^{2}\right\rangle_{u} \frac{1}{2}$, second virial coefficient $A_{2}$ and weight average molecular weight $M_{w}$ in acetone and methyl ethyl ketone were given by: $\left\langle\vec{s}^{2}\right\rangle_{u} \frac{1}{2}=1.47 \times 10^{-1}$ $M_{w}{ }^{0.57}(\AA)$ and $A_{2} \propto M_{w}{ }^{-0.28}$. The Flory's constant $\Phi$ corrected to the perfectly homogeneous specimens were $2.6 \times 10^{28}$ in acetone and $2.8 \times 10^{23}$ in methyl ethyl ketone, respectively, ([ $\left.\eta\right]$ is represented in $\mathrm{ml} / \mathrm{g})$. The values of $b_{0}=\left(\bar{r}_{0}{ }^{2} / P\right)^{\frac{1}{2}},\left(\bar{r}_{0}{ }^{2} / \bar{r}_{f}{ }^{2}\right)^{\frac{1}{2}}$ and $\left(M_{0} \times\left[r_{\theta}\right]_{\theta}\right) / P^{\frac{1}{2}}$, all of which are constants concerning with the stiffness of polymer chain, were calculated. The obtained values were $6.5 \AA, 2.10$ and 78 , respectively. From the comparison with those of other polymers, it was concluded that the stiffness of polymer chain in solution is in the order of: polystyrene $z$ polyvinyl acetate $>$ polymethyl methacrylate.
\end{abstract}

* Research Laboratory, Kurashiki Rayon Co., (Sakazu, Kurashiki, Okayama) 